\title{
Anti-tumor Effects of Cyclolinopeptide on Giant-cell Tumor of the Bone
}

\author{
YUTA TANIGUCHI ${ }^{1}$, NORIO YAMAMOTO ${ }^{1}$, KATSUHIRO HAYASHI $^{1}$, AKIHIKO TAKEUCHI $^{1}$, \\ SHINJI MIWA ${ }^{1}$, KENTARO IGARASHI ${ }^{1}$, TAKASHI HIGUCHI ${ }^{1}$, KENSAKU ABE ${ }^{1}$, \\ HIROTAKA YONEZAWA ${ }^{1}$, YOSHIHIRO ARAKI ${ }^{1}$, SEI MORINAGA ${ }^{1}$, JUNZO KAMEI ${ }^{2}$, \\ ALFARIUS EKO NUGROHO ${ }^{3}$, TOSHIO KANEDA ${ }^{3}$, HIROSHI MORITA ${ }^{3}$ and HIROYUKI TSUCHIYA ${ }^{1}$ \\ ${ }^{1}$ Department of Orthopaedic Surgery, Kanazawa University Graduate School of Medical Sciences, Kanazawa, Japan; \\ ${ }^{2}$ Department of Pathophysiology and Therapeutics, \\ School of Pharmacy and Pharmaceutical Sciences, Hoshi University, Tokyo, Japan; \\ ${ }^{3}$ Faculty of Pharmaceutical Sciences, Hoshi University, Tokyo, Japan
}

\begin{abstract}
Aim: This study aimed to evaluate the antitumor effects of cyclolinopeptide $(C L)$, which suppresses receptor activator of nuclear factor- $k B$ ligand (RANKL) signalling on giant-cell tumours of the bone (GCTB) cells. Materials and Methods: GCTB cell lines were established, and the inhibition of cell growth by $C L$ was evaluated using the water-soluble tetrazolium salt-8 cell proliferation assay, cell cycle assay, and 5-ethynyl-2'-deoxyuridine (EdU) cell proliferation assay. RANKL and runt-related transcription factor 2 (RUNX2) expression levels were evaluated using real-time polymerase chain reaction before and after $C L$ administration. Results: The dose-dependent inhibition of GCTB cells was significantly pronounced in the CL-administered group compared to the non-CL-administered group $(p<0.05)$. In the $C L$-administered group, the ratio of cells in the $G_{0} / G_{1}$ phase was increased, but the ratio of EdU-positive cells was decreased $(p<0.05)$. $R A N K L$ and RUNX2 levels were decreased in the $C L$ administered group $(p<0.05)$. Conclusion: $C L$ has antitumor effects on GCTB in vitro.
\end{abstract}

The incidence of giant-cell tumor of the bone (GCTB), which is classified as an intermediate malignancy in the 2013 WHO classification of tumors (1), is $4 \%-5 \%$ of the total cases of bone tumors (2-5). Approximately $2 \%$ of GCTB

Correspondence to: Norio Yamamoto, MD, Ph.D., Department of Orthopaedic Surgery, Kanazawa University Graduate School of Medical Sciences, 13-1 Takara-machi, Kanazawa, Ishikawa 9208640, Japan. Tel: +81 762652374, Fax: +81 762344261, e-mail: norinori@med.kanazawa-u.ac.jp

Key Words: Cyclolinopeptide, antitumor properties, giant-cell tumor of the bone (GCTB), RANKL signalling. cases result in lung metastasis, which is fatal in some instances $(6,7)$. Curettage along with adjuvant therapy is the most common treatment method used for this tumor; nonetheless, the local recurrence rate is high, at approximately $15 \%-50 \%$. Although the en bloc resection of the tumor can reduce the recurrence rate, loss of function due to resection is a major issue. Furthermore, it is difficult to perform the radical resection of tumors in anatomically difficult locations, such as the spine or pelvis, because an appropriate surgical margin cannot be secured (1).

GCTB is composed of two kinds of cells: osteoclast-like giant cells or its precursor expressing receptor activator of nuclear factor-kB (RANK) and receptor activator of nuclear factor-kB ligand (RANKL) (8). Mesenchymal stromal cells are thought to have proliferative abilities and are important for tumour growth (1).

Giant cells are induced by RANKL produced by proliferating stromal cells and cause bone absorption $(8,9)$. Furthermore, stromal cells express osteoblast markers such as alkaline phosphatase and runt-related transcription factor 2 (RUNX2) (10).

Flax (scientific name: Linum usitatissimum) is an annual grass of Linaceae that has originated in Central Asia and is cultivated all over the world. The dried mature seed is called linseed (flaxseed). Linseed oil, which is obtained by compressing or crushing seeds and extracting them with a solvent, is rich in unsaturated fatty acids, such as $\alpha$-linolenic acid (a $\omega-3$ fatty acid) (11-13). Linseed oil is sold as food or a supplement. Cyclolinopeptide A (CL-A), which is a cyclic peptide extracted from linseed, was first introduced in 1959 by Kaufmann et al. (14). Several studies have reported the cytoprotective and immunosuppressive effects of CL-A (1517). Recently, 10 kinds of CLs, namely, B, C, D, E, F, G, H, I, $\mathrm{J}$, and $\mathrm{K}$, and 5 reductants of CL-F and $\mathrm{G}$ have been introduced 


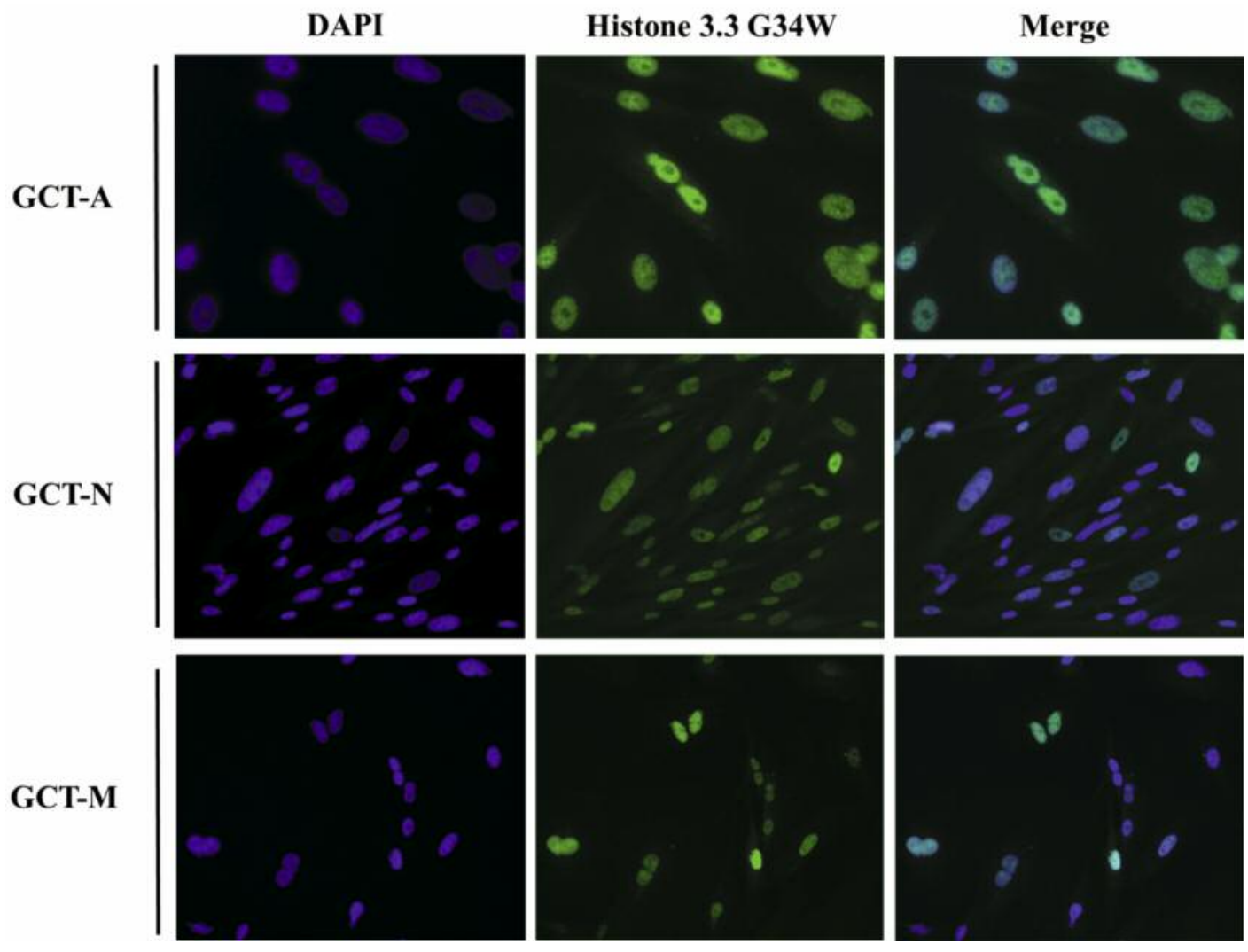

Figure 1. Immunofluorescence for Histone H3.3 G34W. All three established cell lines showed staining with the anti-histone H3.3 G34W antibody.

as new cyclic peptides extracted from linseed (18-25). They have been found to inhibit RANKL signaling and the differentiation of myeloid cells into osteoclasts in mice $(26$, 27). Considering that $\mathrm{CL}$ is derived from natural substances and has low toxicity, new drugs that comprise CL are now being designed as safe drugs for long-term administration (25).

Several studies have shown that RANKL signalling is an important factor for tumour progression in GCTB. Thus, in this study, we evaluate the antitumor effect of CLs, which inhibit RANKL signal, on GCTB.

\section{Materials and Methods}

GCTB sample collection. Following the approval of the ethics committee of our hospital, we obtained consent from three GCTB patients for enrolment in this study. The patients underwent surgical resection and were diagnosed with GCTB. The resected specimens were partially used in the study.

Primary cell lines and cultures. The cell lines of GCTB stromal cells were produced from the collected tissue, as described by Goldring et al. (28). The GCTB tissue was minced with a clean scalpel, soaked in $0.2 \%$ collagenase type 1 (Wako ${ }^{\circledR}$, Osaka, Japan), and incubated for $1 \mathrm{~h}$ at $37^{\circ} \mathrm{C}$ in a $5 \% \mathrm{CO}_{2}$ incubator. The minced cells were then filtered with a cell strainer $(100 \mu \mathrm{m})$ and centrifuged at $300 \times g$ for $4 \mathrm{~min}$. The supernatant was removed and suspended in Dulbecco's Modified Eagle Medium (DMEM) (High Glucose; Wako ${ }^{\circledR}$ ) containing $10 \%$ fetal bovine serum and penicillinstreptomycin solution $\left(\times 100\right.$; Wako $\left.{ }^{\circledR}\right)$. Thereafter, the cells were seeded in a $75 \mathrm{~cm}^{2}$ tissue culture flask (TPP ${ }^{\circledR}$, Trasadingen, Switzerland). Confluent GCTB cells were treated with $0.05 \mathrm{w} / \mathrm{v} \%$ Trypsin-0.53 mmol/1 EDTA-4 Na Solution with Phenol Red $\left(\right.$ Wako ${ }^{\circledR}$ ) and then subcultured to produce cell lines. The cell lines were maintained in a humidified $5 \% \mathrm{CO}_{2}$ incubator at $37^{\circ} \mathrm{C}$.

Immunofluorescence. The presence of the $\mathrm{H} 3 \mathrm{~F} 3 \mathrm{~A}$ mutation in the established cell lines was evaluated using the anti-histone H3.3 G34W rabbit monoclonal antibody (RevMAb Biosciences ${ }^{\circledR}$, San Francisco, CA, USA) (29). RANKL expression was evaluated using anti-RANKL antibody (ab9957; Abcam $^{\circledR}$, Cambridge, UK). The GCTB cells were treated with trypsin. DMEM was added to adjust the cell concentration to $5 \times 10^{4}$ cells $/ \mathrm{ml}$, and $1 \mathrm{ml}$ of cell suspension was spread onto the Nunc ${ }^{\mathrm{TM}}$ Lab-Tek $^{\mathrm{TM}}$ Chamber Slide System (Thermo Scientific ${ }^{\circledR}$, Waltham, MA, USA). The cells were cultured for $24 \mathrm{~h}$. The medium was removed, and the cells were washed with phosphate buffer saline (PBS). The cells were then fixed by treatment with $4 \%$ formalin at room temperature for $10 \mathrm{~min}$, washed several times with PBS, and 


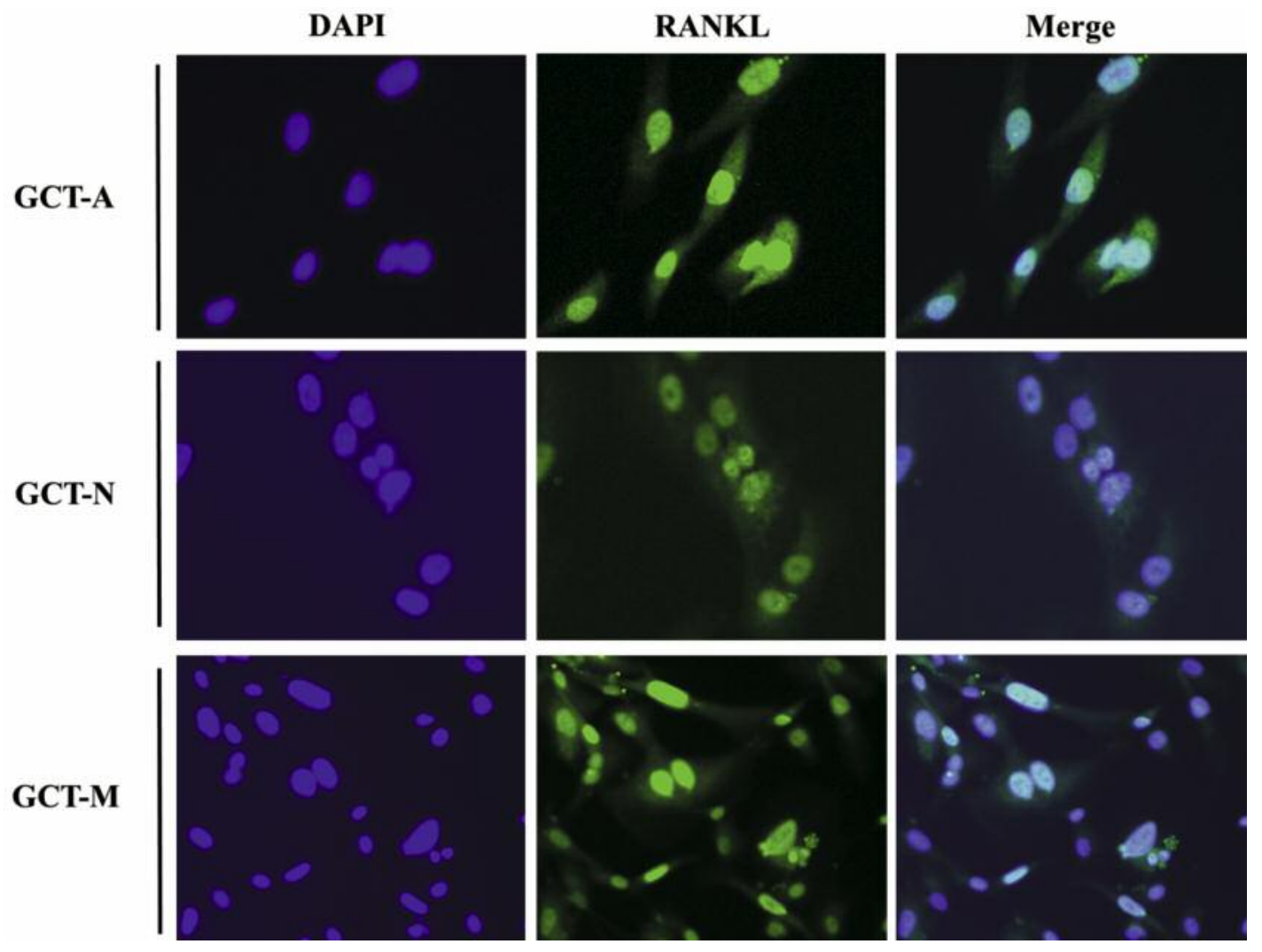

Figure 2. Immunofluorescence for RANKL. All three established cell lines showed staining with the anti-RANKL antibody.

treated with $0.2 \%$ Triton X-100 solution $\left(\mathrm{Wako}^{\circledR}\right.$ ) for $30 \mathrm{~min}$ at room temperature to permeabilize the cell membrane. After washing several times with PBS and treating them with $2 \%$ BSA solution for $30 \mathrm{~min}$, the primary antibody diluent (anti-histone H3.3 G34W, 1:400; RANKL, 1:500) was administered, and the cells were incubated for $30 \mathrm{~min}$ at room temperature. After several washes with PBS, the secondary antibody (FITC goat antirabbit $\operatorname{IgG} ; 1: 200$, Becton, Dickinson and Company ${ }^{\circledR}$ Franklin Lakes, New Jersey, USA) was administrated, and the cells were incubated at room temperature for $30 \mathrm{~min}$. After several washes with PBS, two drops/well of NucBlue Live Cell Stain Ready Probes reagent (Invitrogen ${ }^{\circledR}$, Waltham, MA, USA) were added to the cells and allowed to stay at room temperature for $5 \mathrm{~min}$. The staining of the cells was observed under a fluorescence microscope (BZ-9000E KEYENCE ${ }^{\circledR}$, Osaka, Japan).

Extraction of CL from linseed oil. Linseed oil was separated using silica gel column chromatography $(\mathrm{Hexane} / \mathrm{EtOH})$, and fractions containing $\mathrm{CL}$ were combined. The average $\mathrm{CL}$ content at this stage was $\sim 40 \%$ according to HPLC.

Water-soluble tetrazolium salt-8 (WST-8) assay. GCTB cells were treated with trypsin, and the cell suspension was seeded in 96-well tissue culture plates $\left(\mathrm{TPP}^{\circledR}\right)$ at a concentration of $5 \times 10^{3}$ cells/well. After administering $0,1.25,2.5,5,10$, and $20 \mathrm{nM}$ of $\mathrm{CL}$, the cells were incubated for $72 \mathrm{~h}$ at $37^{\circ} \mathrm{C}$ in a humidified, $5 \% \mathrm{CO}_{2}$ atmosphere incubator. To measure the absorbance, $10 \mu \mathrm{l} /$ well of Cell Counting Kit-8 reagent (DOJINDO ${ }^{\circledR}$, Kumamoto, Japan) were, and cell viability was evaluated using the iMark $^{\mathrm{TM}}$ Microplate Absorbance Reader (Bio-Rad ${ }^{\circledR}$, Hercules, CA, USA). As a control, denatured CL (created by heating for $30 \mathrm{~min}$ at $70^{\circ} \mathrm{C}$ ) was administered to the cells at concentrations of $0,1.25,2.5,5,10$, and $20 \mathrm{nM}$. The cells were cultured for $72 \mathrm{~h}$ and were evaluated in the same manner as described above.

Cell cycle assay. The GCTB cells were treated with trypsin, and the cell suspension was seeded $\left(1 \times 10^{5}\right.$ cells $\left./ \mathrm{ml}\right)$ in a $60.1 \mathrm{~cm}^{2}$ tissue culture dish $\left(\mathrm{TPP}^{\circledR}\right)$. After the administration of $10 \mathrm{nM}$ CL to each dish, the cells were incubated for $72 \mathrm{~h}$. Cells without CL were incubated for $72 \mathrm{~h}$ and were used as controls. The incubated GCTB cells were treated with trypsin. Thereafter, approximately $1 \times 10^{6}$ cells were transferred to $1.5 \mathrm{ml}$ microcentrifuge tubes (Watson ${ }^{\circledR}$, Kobe, Japan) and centrifuged at $300 \times g$ for $5 \mathrm{~min}$. The cells were then washed once with PBS, and $1 \mathrm{ml}$ of ice-cold $70 \%$ ethanol was slowly added, and the cell concentration was adjusted to $5 \times 10^{5}-1 \times 0^{6}$ cells $/ \mathrm{ml}$. The cells were fixed at $-20^{\circ} \mathrm{C}$ for $3 \mathrm{~h}$. Thereafter, $200 \mu \mathrm{l}$ were transferred to new microcentrifuge tubes, centrifuged at $300 \times$ $g$ for 5 min, and washed with PBS. Muse ${ }^{\circledR}$ Cell Cycle reagent $(200$ $\mu \mathrm{l}$; Propidium Iodide, Ribonuclease A, Luminex ${ }^{\circledR}$, Austin, TX, USA) was added to each microcentrifuge tube and incubated at 
room temperature in the dark for $30 \mathrm{~min}$. Measurements were obtained using the Muse ${ }^{\circledR}$ Cell Analyzer (Luminex ${ }^{\circledR}$ ).

$E d U$ assay. GCTB cells were treated with trypsin, and the cell suspension was seeded in a $60.1 \mathrm{~cm}^{2}$ tissue culture dish $\left(1 \times 10^{5}\right.$ cells $/ \mathrm{ml}$ ) and incubated with $10 \mathrm{nM} \mathrm{CL}$ for $48 \mathrm{~h}$. The controls consisted of cells incubated without CL. GCTB cells were treated with trypsin, and the cell suspension was seeded in the Nunc тм Lab-Tek $^{\text {TM }}$ Chamber Slide System (Thermo Scientific ${ }^{\circledR}$, Waltham, MA, USA) at a concentration of $5 \times 10^{3}$ cells/well. After the administration of $1 \mu \mathrm{l}$ of $10 \mathrm{mM}$ EdU stock solution to each well, the cells were incubated for $3 \mathrm{~h}$. The cells were fixed with $3.7 \%$ formaldehyde in PBS and then incubated at room temperature for $15 \mathrm{~min}$. After the removal of the fixative, the cells were washed twice with $3 \%$ BSA in PBS. The washing solution was discarded, 1 $\mathrm{ml}$ of $0.5 \%$ Triton ${ }^{\circledR} \mathrm{X}-100$ in PBS was added to each well, and the cells were incubated at room temperature for $20 \mathrm{~min}$. After washing twice with $3 \%$ BSA in PBS, $0.5 \mathrm{ml}$ of Click-iT ${ }^{\circledR}$ reaction cocktail $\left(1 \times \mathrm{Click} \mathrm{iT}{ }^{\circledR}\right.$ reaction buffer, $\mathrm{CuSO}_{4}$, and Alexa Fluor ${ }^{\circledR}$ azide, reaction buffer additive) was added to each well. The cells were shielded and incubated at room temperature for $30 \mathrm{~min}$. The reaction cocktail was discarded, and the cells were washed once with 3\% BSA in PBS. The nucleic acid of the cells was stained with NucBlue Live Cell Stain Ready Probes reagent (Invitrogen ${ }^{\circledR}$ ). The cells were observed using a fluorescence microscope (BZ - 9000E $\left.\mathrm{KEYENCE}^{\circledR}\right)$. The total number of cells in five visual fields and the number of EdU-positive cells were counted using Image $J^{\circledR}(30,31)$. The ratio of EdU-positive cells was calculated and compared statistically between the CL-administered group and the control group (Mann-Whitney $U$-test).

Real-time polymerase chain reaction $(P C R)$. GCTB cells were treated with trypsin, and cell suspensions (approximately $5 \times 10^{5}$ ) were seeded in six-well tissue culture test plates $\left(\mathrm{TPP}^{\circledR}\right)$. The cells were incubated with $10 \mathrm{nM} \mathrm{CL}$ for $48 \mathrm{~h}$; control cells were incubated for $48 \mathrm{~h}$ without CL. After the removal of DMEM and washing with PBS, TRIZOL® Reagent ( $1 \mathrm{ml} /$ well; Invitrogen $\left.{ }^{\circledR}\right)$ was added, and the cells were detached using a cell lifter (Corning ${ }^{\circledR}$, Corning, NY, USA). The cell suspension was transferred to $1.5 \mathrm{ml}$ microcentrifuge tubes and incubated at $30^{\circ} \mathrm{C}$ for $5 \mathrm{~min}$. Subsequently, $0.2 \mathrm{ml}$ chloroform (Wako ${ }^{\circledR}$ ) was added to each tube, and the mixture was vortexed for $15 \mathrm{~s}$ and incubated at $30^{\circ} \mathrm{C}$ for 3 min. The mix was centrifuged at $4^{\circ} \mathrm{C}$ and $12000 \times g$ for $15 \mathrm{~min}$, and the aqueous layer was transferred to new microcentrifuge tubes. Isopropyl alcohol $\left(0.4 \mathrm{ml}\right.$; Wako $\left.{ }^{\circledR}\right)$ was added to the tube, and the mixture was incubated at $30^{\circ} \mathrm{C}$ for $10 \mathrm{~min}$. Thereafter, it was centrifuged at $12000 \times g\left(4^{\circ} \mathrm{C}\right)$ for $10 \mathrm{~min}$. The supernatant was removed and the RNA pellet was vortexed once with $70 \%$ ethanol. After centrifugation at $4^{\circ} \mathrm{C}$ and $7500 \times g$ for $5 \mathrm{~min}$, the supernatant was discarded, and the RNA pellet was air dried for $10 \mathrm{~min}$. The pellet was then dissolved in RNase free water, and cDNA was prepared using the Affinity Script QPCR cDNA Synthesis Kit (Agilent ${ }^{\circledR}$, Santa Clara, CA, USA). A mix containing $10 \mu \mathrm{l}$ firststrand master mix, $3 \mu$ l oligo (dT) primer, and $1 \mu$ Affinity Script $\mathrm{RT} / \mathrm{RN}$ ase Block enzyme was added to each $100 \mathrm{ng}$ of RNA. The mixture was incubated as follows: $25^{\circ} \mathrm{C}$ for 5 min using a T100 10 Thermal Cycler (Bio-Rad ${ }^{\circledR}$ ) to allow for the annealing of the primer, $42^{\circ} \mathrm{C}$ for $45 \mathrm{~min}$ to allow for cDNA synthesis, and $95^{\circ} \mathrm{C}$ for $5 \mathrm{~min}$ to terminate the cDNA synthesis reaction. Thereafter, $3 \mu \mathrm{cDNA}$ was mixed with $30 \mu$ of $2 \times$ QuantiTect SYBR Green 2 PCR Master
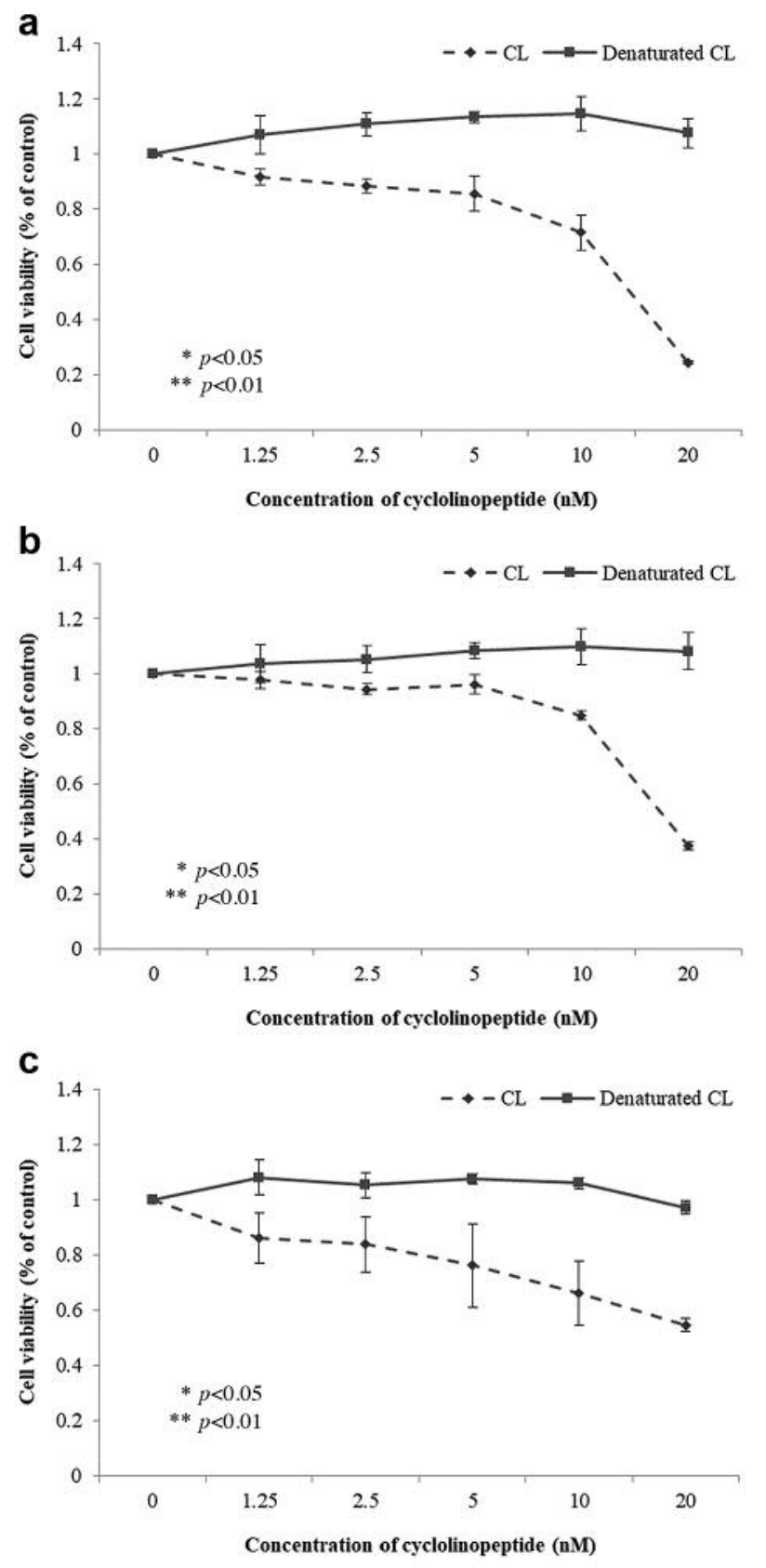

Figure 3. The effect of cyclolinopeptide (CL) on the cell viability of giant-cell tumor of the bone (GCTB) stromal cells. a) GCT-A, b) GCT$N$, c) GCT-M. Cell viability was decreased in the CL-administered group in a concentration-dependent manner, whereas no decrement was observed in the denatured $C L-$ administered group $\left({ }^{*} p<0.05, * * p<0.01\right)$.

Mix (HotStarTaq ${ }^{\circledR}$ DNA Polymerase QuantiTect SYBR Green PCR Buffer dNTP mix, including dUTP SYBR Green I, ROX ${ }^{\mathrm{TM}}$ passive reference dye, $5 \mathrm{mM} \mathrm{MgCl}_{2}$ ) and $0.5 \mu \mathrm{M}$ of the primer. The primers used were as follows: glyceraldehyde 3-phosphate dehydrogenase (GAPDH) forward 5'TGCACCACCAACTGCTTAGC 3' and 


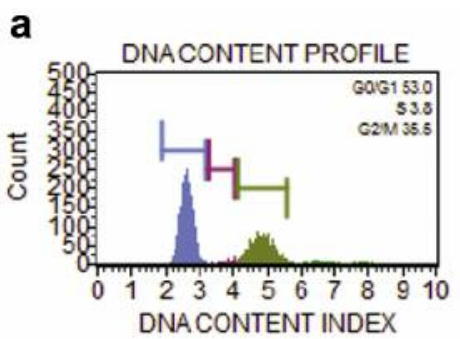

CL-

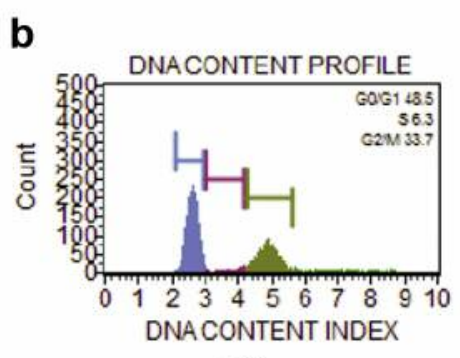

CL-

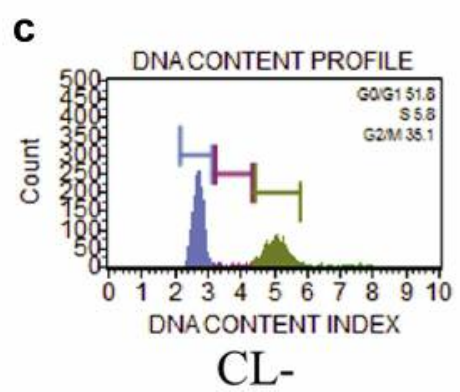

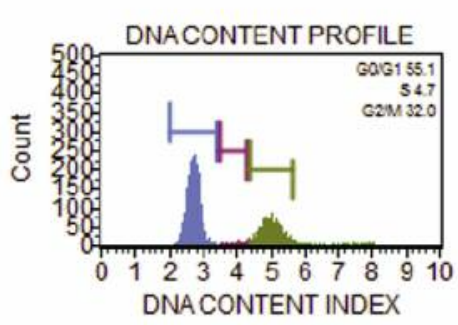

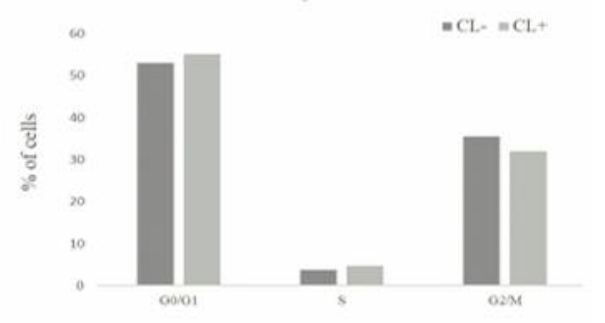

$\mathrm{CL}+$
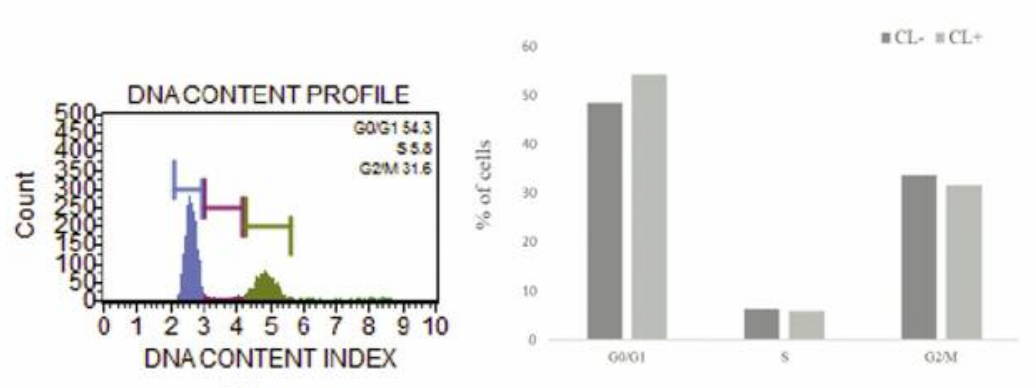

$\mathrm{CL}+$

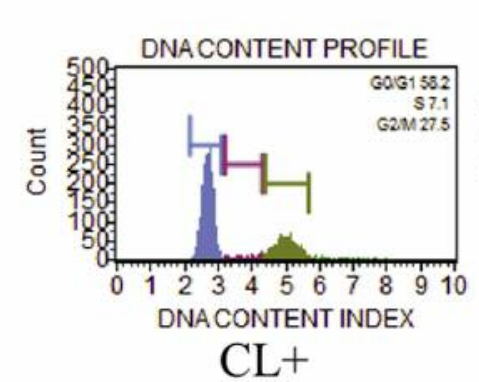

Figure 4. The effect of cyclolinopeptide (CL) on the cell cycle of giant-cell tumor of the bone (GCTB) stromal cells. a) GCT-A, b) GCT-N, c) GCT$M$. The ratio of cells in the $G_{0} / G_{1}$ phase was increased in the $C L$-administered group compared with the control group.

reverse 5' GGCATGGACTGTGGTCATGAG 3', RANKL forward 5'GCCTTTCAAGGAGCTGTGCAA 3' and reverse 5' ATCTAAC CATGAGCCATCCACCAT 3', and RUNX2 forward 5' TCTGGCC TTCCACTCTCAGT $3^{\prime}$ and reverse 5' AAGGTGGCTGG ATAGTGCAT 3'using the StepOne Real-Time PCR system (Applied Biosystems ${ }^{\circledR}$, Waltham, MA, USA). Real-time PCR was performed as follows: initial activation at $95^{\circ} \mathrm{C}$ for $10 \mathrm{~min}, 40$ cycles of incubation at $95^{\circ} \mathrm{C}$ for $30 \mathrm{sec}$ (denaturation), annealing at $55^{\circ} \mathrm{C}$ for $1 \mathrm{~min}$, and final extension at $72^{\circ} \mathrm{C}$ for $1 \mathrm{~min}$.

Cycle threshold $(\mathrm{Ct})$ values were calculated in each group. GAPDH expression was used as an internal control. The relative change in expression was determined according to the $2^{-\Delta \Delta \mathrm{Ct}}$ method. The amount of mRNA expression in the CL-administered and control groups were statistically analyzed using the Wilcoxon signed-rank test.

Statistical analysis. All statistical analyses were performed with EZR (Saitama Medical Center, Jichi Medical University, Saitama, Japan), which is a graphical user interface for R 2.13.0 ( $\mathrm{R}$ Foundation for Statistical Computing, Vienna, Austria). EZR is a modified version of $\mathrm{R}$ commander (version 1.6-3) that is designed to add statistical functions that are used frequently in biostatistics (32).

\section{Results}

Confirmation of established GCTB cell lines. To confirm the established cell lines as GCTB stromal cells, the cells were stained with anti-histone H3.3 G34W, is a driver gene mutation in GCTB stromal cells, and anti-RANKL antibody, which is highly expressed in GCTB stromal cells. All three established cell lines showed staining for antihistone H3.3 G34W (Figure 1) and the anti-RANKL antibody (Figure 2). Therefore, all cell lines were confirmed as GCTB stromal cells. 

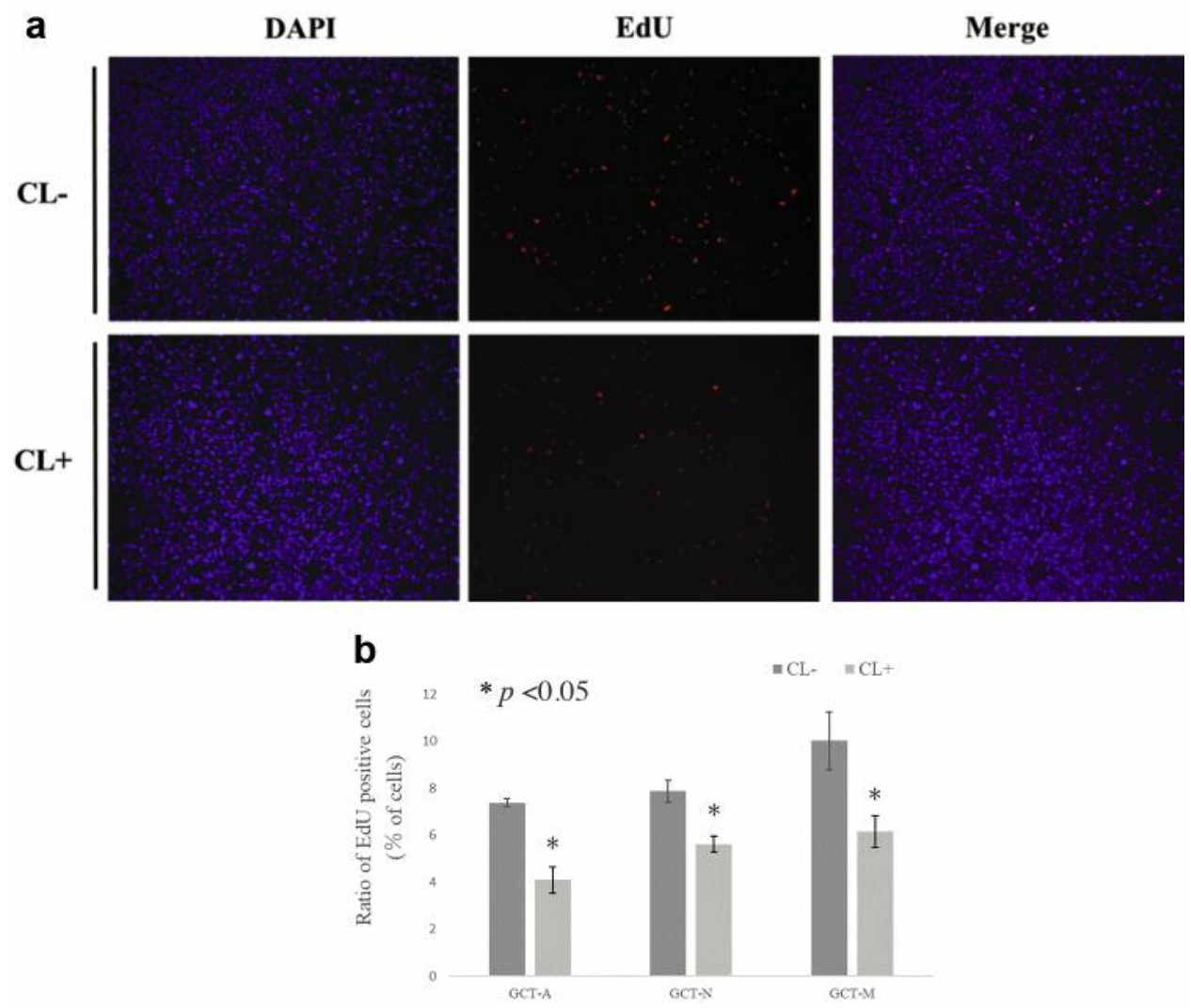

Figure 5. The effect of cyclolinopeptide (CL) on the DNA synthesis of giant-cell tumor of the bone (GCTB) stromal cells. (a) Fluorescence microscope. (b) Ratio of EdU-positive cells. The ratio of EdU-positive cells was decreased in the CL-administered group compared with the control group $(* p<0.05)$.

Effect on the cell proliferation of GCTB stromal cells. To assess the effect of CL on the cell viability of GCTB stromal cells, WST-8 assay was performed. The cell viability was decreased in the CL-administered group concentrationdependently, but not in the denatured CL-administered group. Cell viability was significantly different between the two groups (Figure 3), thus indicating that CL decreased the cell viability of GCTB stromal cells.

To investigate the mechanism by which CL inhibits GCTB viability, cell cycle assay using flow cytometry and EdU assay were performed. In cell cycle assay, the ratio of cells in the $G_{0} / G_{1}$ phase was increased in the CL-administered group compared with the control group (Figure 4). In EdU assay, the ratio of EdU-positive cells was decreased in the CL-administered group compared with the control group (Figure 5a) and the difference was statistically significant (Figure 5b). These findings indicated that CL inhibited DNA synthesis of GCTB stromal cells.

Effect on the molecular biology of GCTB stromal cells. To investigate the effect of CL on the molecular biology of GCTB stromal cells, real-time PCR was performed. The expression of $R A N K L \mathrm{mRNA}$ was significantly decreased in the CL-administered group compared with the control group (Figure 6a). Similarly, RUNX2, which is upstream of RANKL and is highly expressed in GCTB stromal cells, was significantly decreased in the CL-administered group compared with the control group (Figure 6b). In contrast, the expression of $c$-fos mRNA in the CL-administered group was not significantly different from that in the control group (Figure 6c). These findings indicated that CL decreased the mRNA expression levels of RANKL and RUNX2 but not $c$-fos in GCTB stromal cells.

\section{Discussion}

In this study, we established GCTB cell lines from clinical specimens because they are not commercially available. The cell lines were established according to the report by Goldring et al. (28) and were confirmed by examining the presence of the H3F3A mutation, which is a driver gene mutation in GCTB stromal cells, and the expression of RANKL, which is highly expressed in GCTB stromal cells, via immunofluorescence (8, $9,29)$. In the WST-8 assay, which was used to examine the 

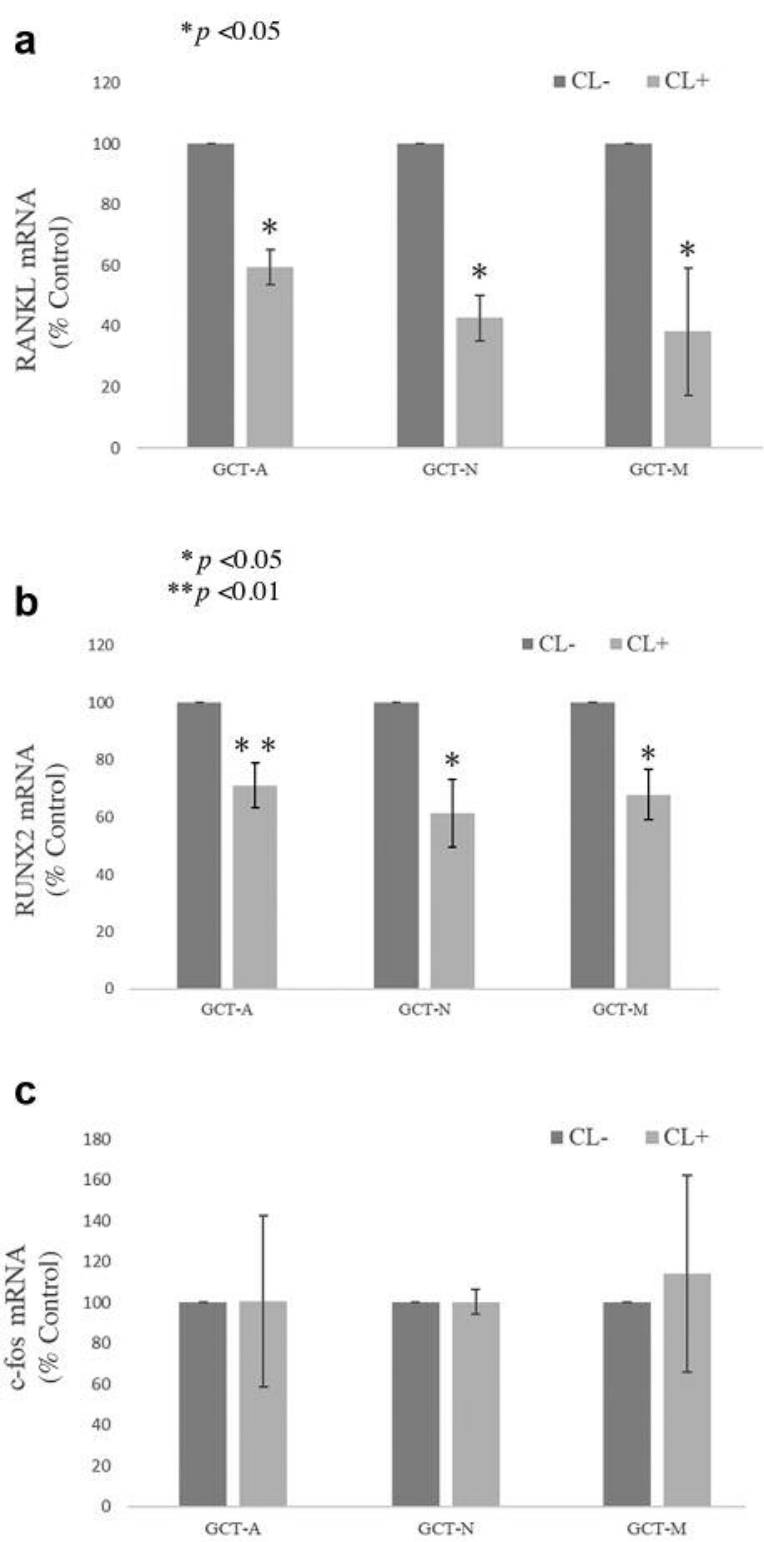

Figure 6. Effect on the expression of RANKL, RUNX2 and c-fos of giantcell tumor of the bone (GCTB) stromal cells. (a) RANKL: The expression levels of RANKL mRNA were decreased in the $C L$ administered group compared with the control group $(* p<0.05)$. (b) RUNX2: The expression levels of RUNX2 mRNA were decreased in the $C L$-administered group compared with the control group $(* p<0.05$, $\left.{ }^{*} p<0.01\right)$. (c) c-fos: The expression levels of c-fos mRNA were not significantly different from that in the control group.

antitumor effect of CL, the number of live cells decreased in a concentration-dependent manner in all cell lines treated with CL. Thereafter, the mechanism by which this antitumor effect was exerted was examined using the cell cycle assay and flow cytometry. The number of cells in the $G_{0} / G_{1}$ phase was found to be increased in cells treated with CL. To assess the effect on
DNA synthesis, the EdU assay was performed, which showed a decrease in the number of EdU-positive cells. These results indicated that the antitumor effect of $\mathrm{CL}$ is based on the inhibition of cell proliferation via the suppression of DNA synthesis.

It is known that GCTB stromal cells strongly express $R A N K L$. Activation of RANK-RANKL signalling induces bone destruction via the development of the giant cells $(8,9)$. The effect of CL on RANKL expression was evaluated by real-time PCR, which showed a decrease in the expression of this gene in all cell lines in the CL-administrated group. This finding suggested the possibility that CL prevents the bone destruction in GCTB. $R U N X 2$, which is upstream of $R A N K L$ (33), is known to be associated with cell proliferation $(34,35)$. In the current study, CL suppressed the expression of RUNX2, which may be the key mechanism responsible for the suppression of $R A N K L$ expression and cell proliferation in the GCTB cells.

Previous studies have shown that CL-J, which is a cyclolinopeptide, selectively suppresses the MEK-ERK-c-fos pathway because of RANKL stimulation during the process of differentiation into osteoclasts (27). In the present study, we investigated the expression of $c$-fos in the GCTB cells and found that CL did not affect $c$-fos expression. Further studies are required to evaluate the effects of CL on other factors such as the upstream factors of RUNX 2 or other signalling pathways.

Drug therapy using anti-RANKL antibody (denosumab) has been reported to be effective for GCTB. By inhibiting the RANK-RANKL signalling in GCTB, denosumab suppresses bone destruction by preventing the development of giant cells $(36,37)$. However, denosumab cannot eliminate stromal cells, and the proliferation of stromal cells is maintained after denosumab treatment (38). Furthermore, the long-term use of denosumab presents problems such as abnormal bone metabolism and malignant transformation of the tumour (39-42). By contrast, flax is already widely consumed as a health food supplement (11). It has been reported that $\mathrm{CL}$, which is an extract from flax, inhibits osteoclast differentiation in a dose-dependent manner without affecting normal cell viability (26). Therefore, CL might be a safer therapeutic agent than denosumab.

\section{Conclusion}

The findings of this study suggested that CL has antitumor effects on GCTB in vitro. In the future, drugs developed on the basis of CL are expected to be new therapeutic agents for GCTB.

\section{Conflicts of Interest}

The Authors declare no conflicts of interest associated with this manuscript. 


\section{Authors' Contributions}

Yuta Taniguchi, Norio Yamamoto and Toshio Kaneda designed the study. Yuta Taniguchi wrote the initial draft of the manuscript. Norio Yamamoto, Akihiko Takeuchi and Toshio Kaneda contributed to analysis and interpretation of data, and assisted in the preparation of the manuscript. Junzo Kamei, Ailfarius Eko Nugroho, Toshio Kaneda and Hiroshi Morita provided the cyclolinopeptide for the experiments. Hiroyuki Tsuchiya supervised the project as the head of department. All other authors have contributed to data collection and interpretation, and critically reviewed the manuscript. All Authors approved the final version of the manuscript, and agreed to be accountable for all aspects of the work, ensuring that questions related to the accuracy or integrity of any part of the work are appropriately investigated and resolved.

\section{Acknowledgements}

The Authors would like to thank Enago (www. enago. jp) for the English language review.

\section{References}

1 Fletcher CD, Bridge JA, Hongendroorn PC and Mertens F (eds.). WHO Classification of Tumours and Soft Tissue and Bone. Lyon: IARC, pp. 321-323, 2013.

2 Campanacci M, Baldini N, Boriani S and Sudanese A: Giant-cell tumor of bone. J Bone Joint Surg Am 69: 106-114, 1987. PMID: 3805057.

3 Dorfman HD and Czerniak B: Vascular lesions. In: Bone tumors. Dorfman HD, Czerniak B (eds.). Mosby: St Louis: pp. 559-608, 1998.

4 Schajowicz F: Giant-cell tumours (osteoclastoma). In: Tumours and tumour-like lesions of bone. Schajowiccz F (ed.). SpringerVerlag: Berlin-Heidelberg-New York; pp. 403-406; 540-551, 1994.

5 Unni KK and Inwards CY: Dahlin's bone tumors: general aspects and data on 11087, cases. Sixth edition. Lippincott Williams \& Williams: Philadelphia; pp. 179-183; 310-316, 2010.

6 Masui F, Ushigome S and Fujii K: Giant cell tumor of bone: a clinicopathologic study of prognostic factors. Pathol Int 48: 723729, 1998. PMID: 9778111. DOI: 10.1111/j.1440-1827.1998. tb03973.x

7 Siebenrock KA, Unni KK and Rock MG: Giant-cell tumour of bone metastasising to the lungs. A long-term follow-up. J Bone Joint Surg $\mathrm{Br}$ 80: 43-47, 1998. PMID: 9460951. DOI: 10.1302/0301-620x.80b1.7875

8 Zheng MH, Robbins $\mathrm{P}$, Xu J, Huang L, Wood DJ and Papadimitriou JM: The histogenesis of giant cell tumour of bone: a model of interaction between neoplastic cells and osteoclasts. Histol Histopathol 16: 297-307, 2001. PMID: 11193206. DOI: 10.14670/HH-16.297

9 Lau YS, Sabokbar A, Gibbons CL, Giele H and Athanasou N: Phenotypic and molecular studies of giant-cell tumors of bone and soft tissue. Hum Pathol 36: 945-954, 2005. PMID: 16153456. DOI: 10.1016/j.humpath.2005.07.005

10 Huang L, Teng XY, Cheng YY, Lee KM and Kumta SM: Expression of preosteoblast markers and Cbfa-1 and Osterix gene transcripts in stromal tumour cells of giant-cell tumour of bone. Bone 34: 393-401, 2004. PMID: 15003787. DOI: 10.1016/ j.bone.2003.10.013

11 Shim YY, Gui B, Arnison PG, Wang Y and Reaney M: Flaxseed (Linum usitatissimum L.) bioactive compounds and peptide nomenclature: A review. J T Trends Food Sci Technol 38: 5-20, 2014. DOI: $10.1016 /$ j.tifs.2014.03.011

12 Aladedunye F, Sosinska E and Przybylski R: Flaxseed Cyclolinopeptides: Analysis and Storage Stability. Am Oil Chem Soc 90: 419-428, 2013. DOI: 10.1007/s11746-012-2173-0

13 Schmidt TJ, Klaes M and Sendker J: Lignans in seeds of Linum species. Phytochemistry 82: 89-99, 2012. PMID: 22854497. DOI: $10.1016 /$ j.phytochem.2012.07.004

14 Kaufmann HP and Tobschirbel A: Über ein Oligopeptid aus Leinsamen. Chemische Berichte-Recueil 92: 2805-2809, 1959. DOI: $10.1002 /$ cber.19590921122

15 Wieczorek Z, Bengtsson B, Trojnar J and Siemion IZ: Immunosuppressive activity of cyclolinopeptide A. Pept Res 4: 275-283, 1991. PMID: 1802239.

16 Picur B, Cebrat M, Zabrocki J and Siemion IZ: Cyclopeptides of Linum usitatissimum. J Pept Sci 12: 569-574, 2006. PMID: 16878298. DOI: $10.1002 / p s c .779$

17 Gaymes TJ1, Cebrat M, Siemion IZ and Kay JE: Cyclolinopeptide A (CLA) mediates its immunosuppressive activity through cyclophilin-dependent calcineurin inactivation. FEBS Lett 24: 224-227, 1997. PMID: 9414131. DOI: 10.1016/ s0014-5793(97)01345-8

18 Morita H, Shishido A, Matsumoto T, Itokawa H and Takeya K: Cyclolinopeptides B - E, new cyclic peptides from Linum usitatissimum. Tetrahedron 55: 967-976, 1999. DOI: 10.1016/S0040-4020(98)01086-2

19 Matsumoto T, Shishido A, Morita H, Itokawa, H and Takeya K: Cyclolinopeptides F-I, cyclic peptides from linseed. Phytochemistry 57: 251-260, 2001. PMID: 11382241. DOI: 10.1016/s0031-9422(00)00442-8

20 Stefanowicz P: Detection and sequencing of new cyclic peptides from linseed by electrospray ionization mass spectrometry. Acta Biochim Pol 48: 1125-1129, 2001. PMID: 11995978.

21 Stefanowicz P: electrospray mass spectrometry and tandem mass spectrometry of the natural mixture of cyclic peptides from linseed. Eur J Mass Spectrom 10: 665-671, 2004. PMID: 15531800. DOI: $10.1255 /$ ejms.657

22 Okinyo-Owiti DP, Young L, Burnett PG and Reaney MJ: New flaxseed orbitides: Detection, sequencing, and $15 \mathrm{~N}$ incorporation. Peptide Sci 102: 168-175, 2014. DOI: 10.1002/bip.22459

23 Burnett PG, Jadhav PD, Okinyo-Owiti, DP, Poth AG and Reaney MJ: Glycine-containing flaxseed orbitides. Nat Prod 78: 681688, 2015. PMID: 25781981. DOI: 10.1021/np5008558

24 Matsumoto T, Shishido A, Morita H, Itokawa H and Takeya K: Cyclolinopeptides F-I, cyclic peptides from linseed. Phytochemistry 57: 251-260, 2001. PMID: 11382241. DOI: 10.1016/s0031-9422(00)00442-8

25 Jadhav PD, Okinyo-Owiti DP, Ahiahonu PW and Reaney MJ: Detection, isolation and characterisation of cyclolinopeptides $\mathrm{J}$ and $\mathrm{K}$ in ageing flax. Food Chem 138: 1757-1763, 2013. PMID: 23411308. DOI: 10.1016/j.foodchem.2012.10.126

26 Kaneda T, Yoshida H, Nakajima Y, Toishi M, Nugroho AE and Morita H: Cyclolinopeptides, cyclic peptides from flaxseed with osteoclast differentiation inhibitory activity. Bioorg Med Chem Lett 26: 1760-1761, 2016. PMID: 26923696. DOI: 10.1016/ j.bmc1.2016.02.040 
27 Kaneda T, Nakajima Y, Koshikawa S, Nugroho AE and Morita $\mathrm{H}$ : Cyclolinopeptide F, a cyclic peptide from flaxseed inhibited RANKL-induced osteoclastogenesis via downergulation of RANK expression. J Nat Med 73: 504-512, 2019. PMID: 30877416. DOI: 10.1007/s11418-019-01292-w

28 Goldring SR, Dayer JM, Russell RG, Mankin HJ and Krane SM: Response to hormones of cells cultured from human giant-cell tumors of bone. J Clin Endocrinol Metab 46: 425-433, 1978. PMID: 87400. DOI: 10.1210/jcem-46-3-425

29 Amary F, Berisha F, Ye H, Gupta M, Gutteridge A, Baumhoer D, Gibbons R, Tirabosco R, O'Donnell P and Flanagan AM: H3F3A (Histone 3.3) G34W immunohistochemistry: A reliable marker defining benign and malignant giant cell tumor of bone. Am J Surg Pathol 41: 1059-1068, 2017. PMID: 28505000. DOI: 10.1097/PAS.0000000000000859

30 Rasband WS: ImageJ, U. S. National Institutes of Health, Bethesda, Maryland, USA. Available at: http://imagej.nih.gov/ij.

31 Schneider CA, Rasband WS and Eliceiri KW: "NIH Image to ImageJ: 25 years of image analysis". Nat Methods 9: 671-675, 2012. PMID: 22930834.

32 Kanda Y: Investigation of the freely available easy-to-use software 'EZR' for medical statistics. Bone Marrow Transplant 48: 452-458, 2013. PMID: 23208313. DOI: 10.1038/bmt. 2012.244

33 Jiang ZY, Jiang JJ, Ma YS, Li HY, Shi W, Fu PL, Xu CF, Lu JZ, $\mathrm{Fu} \mathrm{D}$ and $\mathrm{Xu}$ JG: Downregulation of miR-223 and miR-19a induces differentiation and promotes recruitment of osteoclast cells in giant-cell tumor of the bone via the Runx2/TWISTRANK/RANKL pathway. Biochem Biophys Res Commun 505: 1003-1009, 2018. PMID: 30309658. DOI: 10.1016/j.bbrc.2018. 10.025

34 Liao Y, Lv G, Wang B, Kuang L and Wang X: Imatinib promotes apoptosis of giant-cell tumor cells by targeting microRNA-30amediated runt-related transcription factor 2. Mol Med Rep 13: 1739-1745, 2016. PMID: 26708080. DOI: $10.3892 / \mathrm{mmr}$. 2015.4722

35 Huang Q, Jiang Z, Meng T, Yin H, Wang J, Wan W, Cheng M, Yan W, Liu T, Song D, Chen H, Wu Z, Xu W, Li Z, Zhou W and Xiao J: MiR-30a inhibits osteolysis by targeting RunX2 in giantcell tumor of bone. Biochem Biophys Res Commun 453: 160165, 2014. PMID: 25264196. DOI: 10.1016/j.bbrc.2014.09.076
36 Thomas D, Henshaw R, Skubitz K, Chawla S, Staddon A, Blay JY, Roudier M, Smith J, Ye Z, Sohn W, Dansey R and Jun S: Denosumab in patients with giant-cell tumour of bone: an openlabel, phase 2 study. Lancet Oncol 11: 275-280, 2010. PMID: 20149736. DOI: 10.1016/S1470-2045(10)70010-3

37 Luengo-Alonso G, Mellado-Romero M, Shemesh S, RamosPascua L and Pretell-Mazzini J: Denosumab treatment for giantcell tumor of bone: a systematic review of the literature. Arch Orthop Trauma Surg 139: 1339-1349, 2019. PMID: 30877429. DOI: $10.1007 / \mathrm{s} 00402-019-03167-\mathrm{x}$

38 Mak IW, Evaniew N, Popovic S, Tozer R and Ghert M: translational study of the neoplastic cells of giant-cell tumor of bone following neoadjuvant denosumab. J Bone Joint Surg Am 96: e127, 2014. PMID: 25100780. DOI: 10.2106/JBJS.M.01332

39 Aponte-Tinao LA, Piuzzi NS, Roitman P and Farfalli GL: a high-grade sarcoma arising in a patient with recurrent benign giant-cell tumor of the proximal tibia while receiving treatment with denosumab. Clin Orthop Relat Res 473: 3050-3055, 2015. PMID: 25758379. DOI: 10.1007/s11999-015-4249-2

40 Broehm CJ, Garbrecht EL, Wood J and Bocklage T: Two cases of sarcoma arising in giant-cell tumor of bone treated with denosumab. Case Rep Med 2015: 767198, 2015. PMID: 26798348. DOI: $10.1155 / 2015 / 767198$

41 Errani C, Tsukamoto S and Mavrogenis AF: How safe and effective is denosumab for bone giant-cell tumour? Int Orthop 41: 2397-2400, 2017. PMID: 28646421. DOI: 10.1007/s00264017-3536-9

42 Zanchetta MB, Boailchuk J, Massari F, Silveira F, Bogado C and Zanchetta JR: Significant bone loss after stopping long-term denosumab treatment: a post FREEDOM study. Osteoporos Int 29: 41-47, 2018. PMID: 28975362. DOI: 10.1007/s00198-0174242-6
Received October 6, 2019

Revised October 24, 2019

Accepted October 25, 2019 